\title{
Blood Enzymes in the de Lange Syndrome
}

\author{
G. F. SMITH, PARVIN JUSTICE, and D. Y. Y. HSIA \\ Stritch School of Medicine, Loyola University, Maywood, Illinois, USA
}

The de Lange syndrome is a clinical entity in which retardation of mental and physical development occurs in association with a number of other characteristic features, involving particularly the face and limbs (Berg et al, 1970). Dahlqvist, Hall, and Källén (1969) reported that galactose-1-phosphate uridyl transferase activity in red blood cells of patients with de Lange syndrome was elevated. More recently, Daniel and Higgins (1971) found increased serum $\alpha$-ketoglutarate and serum glutamate levels in patients with the characteristic features of this syndrome. Since the aetiology and the pathophysiology of the de Lange syndrome has not been established it was decided that a careful look at the red and white blood cell enzymes was indicated in this syndrome.

\section{Material and Methods}

Ten to $20 \mathrm{ml}$ of heparinized blood was obtained from patients and matched controls. The blood was sedimented in the cold for 45-90 minutes with $6 \%$ dextran in normal saline. These were mixed in a ratio of $1 \mathrm{ml}$ of dextran per $5 \mathrm{ml}$ of blood. The white cell rich supernatant was removed to within $0.2 \mathrm{~cm}$ of the red blood cells. For leucocyte glucose-6-phosphate dehydrogenase the blood was sedimented with $3 \%$ fibrinogen solution in Tris buffer $p \mathrm{H} 7.0$ containing $50 \mathrm{mM}$ $\beta$-mercaptoethanol.

Leucocyte and erythrocyte galactose-1-phosphate

Received 27 August 1971.

It is with great regret that I have to report the death of Professor Hsia on 27 January 1972-Ed. uridyl transferase were assayed according to the method of Mellman and Tedesco (1965).

The tests for glucose-6-phosphate dehydrogenase, acid phosphatase, and alkaline phosphatase were done with white cells prepared by washing with $0.2 \%$ saline to lyse the red cells. The white cells for acid phosphates and alkaline phosphates were lysed with $100 \mathrm{mg} \%$ solution of saponin in water. For the glucose-6phosphate dehydrogenase, the white cells were lysed in Tris buffer $0.19 \mathrm{MpH} 8$ containing $10 \mathrm{mg} \%$ saponin and $0.4 \mathrm{mM}$ TPN.

Erythrocyte glucose-6-phosphate dehydrogenase was assayed by the method of Zinkham (1959). Leucocyte glucose-6-phosphate dehydrogenase was assayed by the method of Shih et al (1965). Acid and alkaline phosphatase were assayed using p-nitrophenol phosphate as substrate (Bessey et al, 1946).

\section{Results}

The results of the enzyme studies are seen in Table I. While there were minor differences between the results of the de Lange and control groups, none is statistically significant.

In general, the values for the de Lange patients were more variable than those for the control group suggesting greater heterogeneity. However, there was no evidence of any consistent blood cell enzyme changes as has been described with certain other chromosomal disorders (Hsia et al, 1971).

This study was supported by a grant from the Mental Health Section of the State of Illinois and from the Association for the Aid of Crippled Children. We wish to thank Miss Nancy Becker for her technical assistance.

TABLE I

\begin{tabular}{|c|c|c|c|c|}
\hline & \multicolumn{2}{|r|}{ Controls } & \multicolumn{2}{|r|}{ De Lange } \\
\hline & No. & Mean $\pm S D$ & No. & Mean \pm SD \\
\hline $\begin{array}{l}\text { White blood cells } \\
\text { Galactose-1-phosphate uridyl transferase }\left(\mu \mathrm{M} / \mathrm{hr} / 10^{6} \mathrm{WBC}\right) \\
\text { Glucose-6-phosphate dehydrogenase }\left(\mu \mathrm{M} / \mathrm{hr} / 10^{6} \text { WBC) }\right. \\
\text { Acid phosphatase (mg P/hr/mg protein) } \\
\text { Alkaline phosphatase (mg } \mathrm{P} / \mathrm{hr} / \mathrm{mg} \text { protein) }\end{array}$ & $\begin{array}{r}12 \\
5 \\
11 \\
11\end{array}$ & $\begin{array}{r}14 \cdot 8 \pm 3 \cdot 1 \\
1.08 \pm 0 \cdot 20 \\
147 \cdot 0 \pm 37 \cdot 0 \\
8 \cdot 4 \pm 1 \cdot 6\end{array}$ & $\begin{array}{r}11 \\
5 \\
7 \\
6\end{array}$ & $\begin{array}{r}18 \cdot 5 \pm 5 \cdot 5 \\
0 \cdot 92 \pm 0 \cdot 22 \\
164 \cdot 0 \pm 35 \cdot 0 \\
8 \cdot 8 \pm 3 \cdot 5\end{array}$ \\
\hline $\begin{array}{l}\text { Red blood cells } \\
\text { Galactose-1-phosphate uridyl transferase }(\mu \mathrm{M} / \mathrm{hr} / \mathrm{ml} \mathrm{RBC}) \\
\text { Glucose-6-phosphate dehydrogenase }(\mu \mathrm{M} / \mathrm{hr} / \mathrm{ml} \mathrm{RBC}) \\
\text { 6-Phosphogluconate dehydrogenase }(\mu \mathrm{M} / \mathrm{hr} / \mathrm{ml} \mathrm{RBC})\end{array}$ & $\begin{array}{r}12 \\
8 \\
6\end{array}$ & $\begin{array}{l}5 \cdot 7 \pm 1 \cdot 8 \\
1.69 \pm 0 \cdot 3 \\
1.63 \pm 0.31\end{array}$ & $\begin{array}{r}13 \\
8 \\
6\end{array}$ & $\begin{array}{l}6 \cdot 0 \pm 2 \cdot 0 \\
1 \cdot 87 \pm 0.49 \\
1.92 \pm 0.45\end{array}$ \\
\hline
\end{tabular}




\section{REFERENCES}

Berg, J. M., McCreary, B. D., Ridler, M. A. C., and Smith, G. F. (1970). The De Lange Syndrome. Pergamon Press, Oxford.

Bessey, O. A., Lowry, O. H., and Brock, M. J. (1946). Method for rapid determination of alkaline phosphatase with 5 cubic millimetres of serum. Fournal of Biological Chemistry, 164, 321-329.

Dahlqvist, A., Hall, B., and Källén (1969). Blood cell galactos1-phosphate uridyl transferase activity in dysplastic patients, with and without chromosomal aberrations. Human Heredity, 19, 628-640.

Daniel, W. L. and Higgins, J. V. (1971). Biochemical and genetic investigation of the De Lange syndrome. American fournal of Diseases of Children, 121, 401-404.
Hsia, D. Y. Y., Justice, P., Smith, G. F., and Dowben, R. M. (1971) Down's syndrome. A critical review of the biochemical and immunological data. American fournal of Diseases of Children, 121, 153-161.

Mellman, W. J. and Tedesco, T. A. (1965). An improved assay of erythrocyte and leukocyte galactose-1-phosphate uridyl transferase: stabilization of the enzyme by a thiol protective reagent. fournal of Laboratory and Clinical Medicine, 66, 980-986.

Shih, L. Y., Wong, P., Inouye, T., Makler, M., and Hsia, D. Y. Y. (1965). Enzymes in Down's syndrome. Lancet, 2, 746-747.

Zinkham, W. H. (1959). An in-vitro abnormality of glutathione metabolism in erythocytes from normal newborns: mechanism and clinical significance. Pediatrics, 23, 18-32. 